\title{
Biomass production and carbon stock in Psidium guajava orchards under hot and sub-humid climate
}

\author{
Sushanta Kumar Naik ${ }^{1, *}$, Pradip Kumar Sarkar ${ }^{1}$, Bikash Das ${ }^{1}$, \\ Arun Kumar Singh ${ }^{1}$ and Bhagwati Prasad Bhatt ${ }^{2}$ \\ ${ }^{1}$ ICAR Research Complex for the Eastern Region, Farming System Research Centre for Hill and Plateau Region, Ranchi 834010 , India \\ ${ }^{2}$ ICAR Research Complex for the Eastern Region, ICAR Parisar, B. V. College, Patna 800014 , India
}

\begin{abstract}
Biomass and carbon storage in orchard ecosystems serve as significant carbon sinks to reduce global warming. The objective of this study was to determine the best-fitted model for non-destructive prediction of dry biomass and carbon stock in Psidium guajava. Richard's model was well validated and considered as best performing with lowest Akaike information criterion of 90.13, root mean square error of $1.69 \mathrm{~kg} \mathrm{tree}^{-1}$ and highest adjusted $R^{2}$ of 0.981 . Tree components like leaves, branches, bole, total above-ground biomass, total below ground biomass and root biomass were fitted in Richard's model for dry biomass and carbon stock prediction. The total dry biomass of $P$. guajava ranged from 0.54 to $9.26 \mathrm{Mg} \mathrm{ha}^{-1}$ in 2-10years-old orchards. The highest mean dry biomass across tree components was observed in branches, while roots recorded the lowest mean biomass. The total carbon stock was 0.27 and $4.19 \mathrm{Mg} \mathrm{ha}^{-1}$ with $\mathrm{CO}_{2}$ sequestration potential of 0.76 and $11.54 \mathrm{Mg} \mathrm{ha}^{-1}$ in 2-year and 10-year-old orchards respectively.
\end{abstract}

Keywords: Biomass production, carbon stock, global warming, growth models, Psidium guajava.

GLOBALLY, the loss of carbon (C) from land-use change has been steadily increasing over the last one and a half centuries, approaching rates of about $2 \mathrm{Pg} \mathrm{C}$ per year, now mostly from tropical deforestation ${ }^{1}$. Increasing concentrations of greenhouse gases (GHGs) in the atmosphere has caused severe climate change and global warming. Fossil-fuel combustion accounts for the major share of these GHGs in the form of carbon dioxide $\left(\mathrm{CO}_{2}\right.$; $58.6 \%$ ). The other sources of GHGs mostly from agricultural systems are methane $\left(\mathrm{CH}_{4}\right)$ and nitrous oxide $\left(\mathrm{N}_{2} \mathrm{O}\right)$ contributing to $14.3 \%$ and $7.9 \%$ respectively, to total collective $\mathrm{CO}_{2}$ equivalent ${ }^{2}$. The present concentration of $\mathrm{CO}_{2}$ in the atmosphere is $409.65 \mathrm{ppm}$ (ref. 3) and it is estimated to reach $500 \mathrm{ppm}$ by 2070 (ref. 4). The amount of carbon stored in different tree species and the rate of

*For correspondence. (e-mail: sushantanaik7@gmail.com) sequestration at a given time vary. The atmospheric $\mathrm{CO}_{2}$ is absorbed by trees as a major sink through photosynthesis and stored in the form of fixed biomass.

Guava (Psidium guajava L.), popularly known as the apple of the tropics, is mostly cultivated in the Asian subcontinent and some other parts of the world. Achieving high yields even from low maintenance of guava orchards has made it unique and successful among commercial growers. At present, in India guava is grown in Jharkhand by small-scale farmers in monoculture or mixed production systems under rainfed condition in an estimated area of 878,000 ha with production of $9,635,000$ tonnes $^{5}$. Guava fruits are used in the preparation of health drinks, beverages, ice creams, candies, desserts and also consumed raw having excellent health benefits. Besides their various uses, guava trees have the potential to increase $\mathrm{C}$ sequestration capacity in non-forested areas. Thus, sufficient information is required about above- and belowground $\mathrm{C}$ stocks. Hence, there was a strong need to develop growth models that will be used to predict the available biomass. The developed models using nondestructive approach will help reduce emissions from deforestation. At the international level, the United Nations Framework Convention on Climate Change ${ }^{6}$ and its Kyoto Protocol demand of information about all tree resources, and not only trees in natural forests. Growing recognition of the potential economic importance of trees outside the forest could help improve the situation in the same way that forest gained attention in terms of reducing $\mathrm{GHGs}^{7}$. Understanding the carbon sequestration potential of guava trees will provide additional benefits to farmers to alleviate poverty and enhance livelihood in carbon market schemes like REDD+.

The assessment of biomass carbon stock estimated through destructive sampling is widely accepted compared to remote-sensing technique used in biomass/carbon stock monitoring and estimation due to accurate estimation on biomass ${ }^{8}$. Terrestrial carbon sequestration is the process through which $\mathrm{CO}_{2}$ is absorbed by trees and plants and thus acts as an important pathway to minimize $\mathrm{CO}_{2}$ concentration in the atmosphere. Information about 
carbon storage potential in guava is scant or not available in the Eastern Plateau and hill regions of India. The present study focuses on dry biomass and carbon stock estimation of guava trees of different ages by applying various growth models.

\section{Materials and methods}

\section{Study area}

The experiment was conducted in 2-10-years-old guava orchards (Cultivar: L-49) from Garkhatanga, Churu and Plandu farm of the ICAR Research Complex for the Eastern Region, Farming System Research Centre for Hill and Plateau Region, Ranchi, Jharkhand, planted from 2006 to 2014. The experimental site is located at $650 \mathrm{~m}$ amsl between $23^{\circ} 16^{\prime} 1.29^{\prime \prime}-23^{\circ} 16^{\prime} 49.08^{\prime \prime} \mathrm{N}$ lat. and $85^{\circ} 20^{\prime} 25.21^{\prime \prime}$ $85^{\circ} 24^{\prime} 32.25^{\prime \prime} \mathrm{E}$ long. The area experiences hot and subhumid climate with average annual rainfall of $1400 \mathrm{~mm}$, of which $80 \%-90 \%$ is received during the rainy season (June-October). Maximum temperature of $37.2^{\circ} \mathrm{C}$ (May) and minimum of $10^{\circ} \mathrm{C}$ (January) with annual average temperature of $23.7^{\circ} \mathrm{C}$ have been recorded in this region. Relative humidity varied between 55\% (winter) and $88 \%$ (rainy season). Soils belong to the order Alfisols and are highly acidic (pH: 4.5-5.5) in reaction with low levels of organic carbon ${ }^{9}$. The guava seedlings were planted at a spacing of $6 \mathrm{~m} \times 6 \mathrm{~m}$ accommodating 275 plants in one hectare. All the fruit orchards received farmyard manure (FYM) at $15 \mathrm{t} \mathrm{ha}^{-1}$ year $^{-1}$. Recommended doses of $\mathrm{N}-\mathrm{P}_{2} \mathrm{O}_{5}-\mathrm{K}_{2} \mathrm{O}$ for guava were $120-60-60 \mathrm{~g}$ tree ${ }^{-1}$ for 1-3-year-old orchards, 240-120 and $120 \mathrm{~g} \mathrm{tree}^{-1}$ for 4-10-year-old orchards ${ }^{10}$.

\section{Sampling and measurement of tree biomass}

The above-ground biomass (AGB) and below-ground biomass (BGB) for 2-10-years-old guava plants were assessed. The guava orchards with spacing of $6 \mathrm{~m} \times 6 \mathrm{~m}$ consist of 275 plants of all ages in 1 ha experimental area. About six plants were randomly selected from the marked area of $15 \mathrm{~m} \times 15 \mathrm{~m}$ in each orchard of 400 sq. m. The measured trees were distributed into five age classes, viz. 2, 4, 6, 8 and 10 years. Six guava trees from each age class were harvested in December 2016, amounting to 30 representative trees. The collar diameter was measured for all the trees in the selected plots at $30 \mathrm{~cm}$ above ground level ${ }^{11}$. The roots were excavated from the soil volume of $1.5 \mathrm{~m}^{3}$ for each harvested tree. The felled trees were separated into roots, bole, branches and leaves. Fresh weight of each tree component was determined by taking samples of $500 \mathrm{~g}$ (fresh weight) and oven-dried at $60^{\circ} \mathrm{C}$ until constant weight was obtained. The dry weight of tree components was estimated using the fresh weight/dry weight factor.

\section{Fitting and validation of models}

Biomass $\left(\mathrm{kg} \mathrm{plant}^{-1}\right)$ and collar diameter $(\mathrm{cm})$ were fitted in nine different predictive models, viz. linear, allometric, logistic, Gompertz, Richard's, negative exponential, monomolecular, Mitcherlich and Weibull to establish functional relationships. Several researches have used plant height and diameter to develop biomass predictive models depending upon the situation and growth habit of plants $^{12}$. In guava, with increase in lateral crown spread there is reduction in the rate growth as age increases. Therefore, total height of the tree is not reliable for developing such relationships in guava. Scatter plots between total biomass and collar diameter were established for all the growth models. For statistical validation of the model, paired $t$ test between the actual weights and model-predicted weights was performed with the null hypothesis that there is no significant difference between observed and predicted values.

Among all models, Richard's model fulfills the validation criteria to the best possible extent and is considered as best performing. This model has been fitted to establish the relationship between biomass of different tree components. The Richard's model is of the form

$$
Y=a /(1+b \exp (-c X))^{(1 / d)}+\varepsilon
$$

where $Y$ represents dry weight of tree component $(\mathrm{kg}$ tree $^{-1}$ ), $X$ the collar diameter of individual trees $(\mathrm{cm})$, $\varepsilon$ the random error term and $a, b, c$ and $d$ represent the model coefficients.

The measured biomass components, viz. bole (stem wood), branches, leaves and roots of 30 guava trees aged 2-10 years were fitted through Richard's model using collar diameter of the tree as an independent variable to calculate the various model coefficients, namely $a, b, c$ and $d$.

The root mean square error (RMSE), relative root mean square error (RMSE\%) and relative mean bias (\%) of biomass were calculated as follows

$$
\begin{aligned}
& \operatorname{RMSE}=\sqrt{\frac{\sum_{i=1}^{n}\left(y_{i}-\hat{y}_{i}\right)^{2}}{n-p},} \\
& \text { Relative RMSE }(\%)=\frac{\operatorname{RMSE}}{\bar{y}} \times 100, \\
& \text { Relative mean bias }(\%)=\frac{\left(\sum_{i=1}^{n} \frac{y_{i}-\hat{y}_{i}}{y_{i}}\right)}{n} \times 100,
\end{aligned}
$$

Here $y_{i}$ is the observed value, $\hat{y}_{i}$ the predicted value, $\bar{y}$ the average observed value, $n$ the number of trees and $p$ is the number of parameters. 
Table 1. Statistical measures of collar diameter and dry biomass component of harvested trees of Psidium guajava

\begin{tabular}{|c|c|c|c|c|c|c|c|c|}
\hline \multirow[b]{2}{*}{ Statistical parameters } & \multirow[b]{2}{*}{$\begin{array}{c}\text { Collar } \\
\text { diameter }(\mathrm{cm})\end{array}$} & \multicolumn{7}{|c|}{ Dry biomass component $\left(\mathrm{kg}\right.$ tree $\left.^{-1}\right)$} \\
\hline & & Branch & Stem & Leaf & Root* & $\begin{array}{l}\text { Above ground } \\
\text { biomass }(\mathrm{AGB})\end{array}$ & $\begin{array}{l}\text { Below ground } \\
\text { biomass (BGB) }\end{array}$ & $\begin{array}{c}\text { Total biomass } \\
(\mathrm{AGB}+\mathrm{BGB})\end{array}$ \\
\hline No. of cases & 30 & 30 & 30 & 30 & 30 & 30 & 30 & 30 \\
\hline Minimum (second year) & 0.84 & 0.00 & 0.07 & 0.036 & 0.028 & 0.112 & 0.028 & 0.15 \\
\hline Maximum (tenth year) & 15.00 & 12.24 & 9.18 & 10.44 & 9.98 & 30.74 & 9.98 & 40.73 \\
\hline Range & 14.16 & 12.24 & 9.11 & 10.40 & 9.95 & 30.63 & 9.96 & 40.57 \\
\hline Sum & 165.24 & 155.99 & 137.52 & 128.71 & 112.61 & 422.23 & 112.61 & 534.84 \\
\hline Median & 5.75 & 5.38 & 4.92 & 4.37 & 3.46 & 14.82 & 3.46 & 18.58 \\
\hline Mean & 5.51 & 5.20 & 4.58 & 4.29 & 3.75 & 14.07 & 3.75 & 17.83 \\
\hline $95 \%$ CI upper & 6.71 & 6.56 & 5.73 & 5.42 & 4.79 & 17.66 & 4.79 & 22.43 \\
\hline $95 \%$ CI lower & 4.30 & 3.84 & 3.44 & 3.16 & 2.71 & 10.49 & 2.71 & 13.23 \\
\hline Standard error (SE) & 0.58 & 0.67 & 0.56 & 0.55 & 0.51 & 1.75 & 0.51 & 2.25 \\
\hline Standard deviation & 3.23 & 3.65 & 3.06 & 3.03 & 2.78 & 9.61 & 2.79 & 12.32 \\
\hline Variance & 10.42 & 13.36 & 9.37 & 9.19 & 7.76 & 92.26 & 7.76 & 151.74 \\
\hline Coefficient of variation & 0.58 & 0.70 & 0.67 & 0.71 & 0.74 & 0.68 & 0.74 & 0.69 \\
\hline Skewness (G1) & 0.61 & 0.01 & -0.18 & 0.09 & 0.30 & -0.10 & 0.30 & -0.035 \\
\hline SE skewness & 0.43 & 0.43 & 0.43 & 0.43 & 0.43 & 0.43 & 0.43 & 0.43 \\
\hline Kurtosis (G2) & 0.94 & -1.14 & -1.36 & -1.04 & -0.77 & -1.27 & -0.77 & -1.19 \\
\hline SE Kurtosis & 0.83 & 0.83 & 0.83 & 0.83 & 0.83 & 0.83 & 0.83 & 0.83 \\
\hline Shaphiro-Wilk's test & 0.94 & 0.94 & 0.92 & 0.95 & 0.95 & 0.93 & 0.95 & 0.94 \\
\hline Shaphiro-Wilk's $P$-value & 0.091 & 0.094 & 0.021 & 0.139 & 0.175 & 0.049 & 0.175 & 0.075 \\
\hline
\end{tabular}

$*$ Root $=$ Taproot + lateral root + fine root.

\section{Biomass and carbon stock estimation}

The total biomass stock $\left(\mathrm{Mg} \mathrm{ha}^{-1}\right)$ was estimated by multiplying tree density $\left(275\right.$ trees $\left.\mathrm{ha}^{-1}\right)$ with the respective biomass in each collar diameter range. Carbon content in oven-dried samples of tree components was estimated by combustion method using CHNS analyzer (Elementar Vario EL III, Hanau, Germany). Carbon stocks in different tree components were obtained by multiplying their biomass values with their average carbon content. Total carbon stock $\left(\mathrm{Mg} \mathrm{ha}^{-1}\right)$ was obtained by multiplying total carbon in the individual trees with tree density. Emitted carbon represents carbon present in the leaves for a short period of 10 months, and complete loss of $\mathrm{C}$ from the leaves occurs in 3.75 years ${ }^{9}$. Stored carbon represents carbon in the bole, roots and branches stored cumulatively for longer periods. Thus, mitigated carbon $=$ stored carbon - emitted carbon. The carbon stored in the plant is expressed as $\mathrm{CO}_{2}$ stored by multiplying the carbon content of the plant with 3.67 .

\section{Statistical analysis}

The different statistical parameters like descriptive statistics (mean, median, variance, coefficient of variation, standard deviation, skewness, kurtosis, Shaphiro-Wilk's test), validation of growth models (model parameter estimates, estimates of asymptotic standard error, confidence interval, adjusted $R^{2}$, Akaike information criterion (AI(c)) RMSE, paired $t$-test between observed and predicted values, fitting of linear regression between observed and predicted values), plotting graphs of resi- dual diagnostics (plots of total biomass against predicted variate, auto-correlation plots of residuals, plot of residuals against collar diameter, plot of residuals against predicted variate) were performed using Systat-12 software $^{13}$.

\section{Results and discussion}

Table 1 summarizes the destructive sampling of 30 guava trees aged 2-10 years with measured collar diameter (CD) and dry biomass component. The CD varied from 0.84 to $15.0 \mathrm{~cm}$, with an average $5.51 \mathrm{~cm}$ among the guava trees. The total AGB ranged from 0.11 to $30.7 \mathrm{~kg}$ tree $^{-1}$ with an average value of $14.07 \mathrm{~kg}^{-1} \mathrm{e}^{-1}$, while total BGB varied from 0.03 and $9.98 \mathrm{~kg}^{-1} \mathrm{e}^{-1}$ with an average value of $3.75 \mathrm{~kg}$ tree $\mathrm{e}^{-1}$ for the entire range of measured guava trees. The Shaphiro-Wilk's $p$-values of all the biomass components $(P>0.02)$, except stem biomass, indicated that distribution is normal. The average total AGB and BGB accounted for $79 \%$ and $21 \%$ respectively. The total biomass as dependent and $\mathrm{CD}$ as independent variables were fitted in different growth models to establish a functional relationship. Vegetative propagation is generally followed for fruit trees and multi stem is allowed below diameter at breast height (DBH; $1.37 \mathrm{~m}$ height from ground) to have more canopy spread and fruit yield. Branching in guava trees generally starts within $50 \mathrm{~cm}$ from the ground level and justifies the use of CD instead of DBH. Due to regular pruning of guava, vertical growth is restricted at a certain height. Thus, CD is the better predictor of biomass compared to height. Rizvi et al. ${ }^{14}$ observed no significant difference in the biomass of 

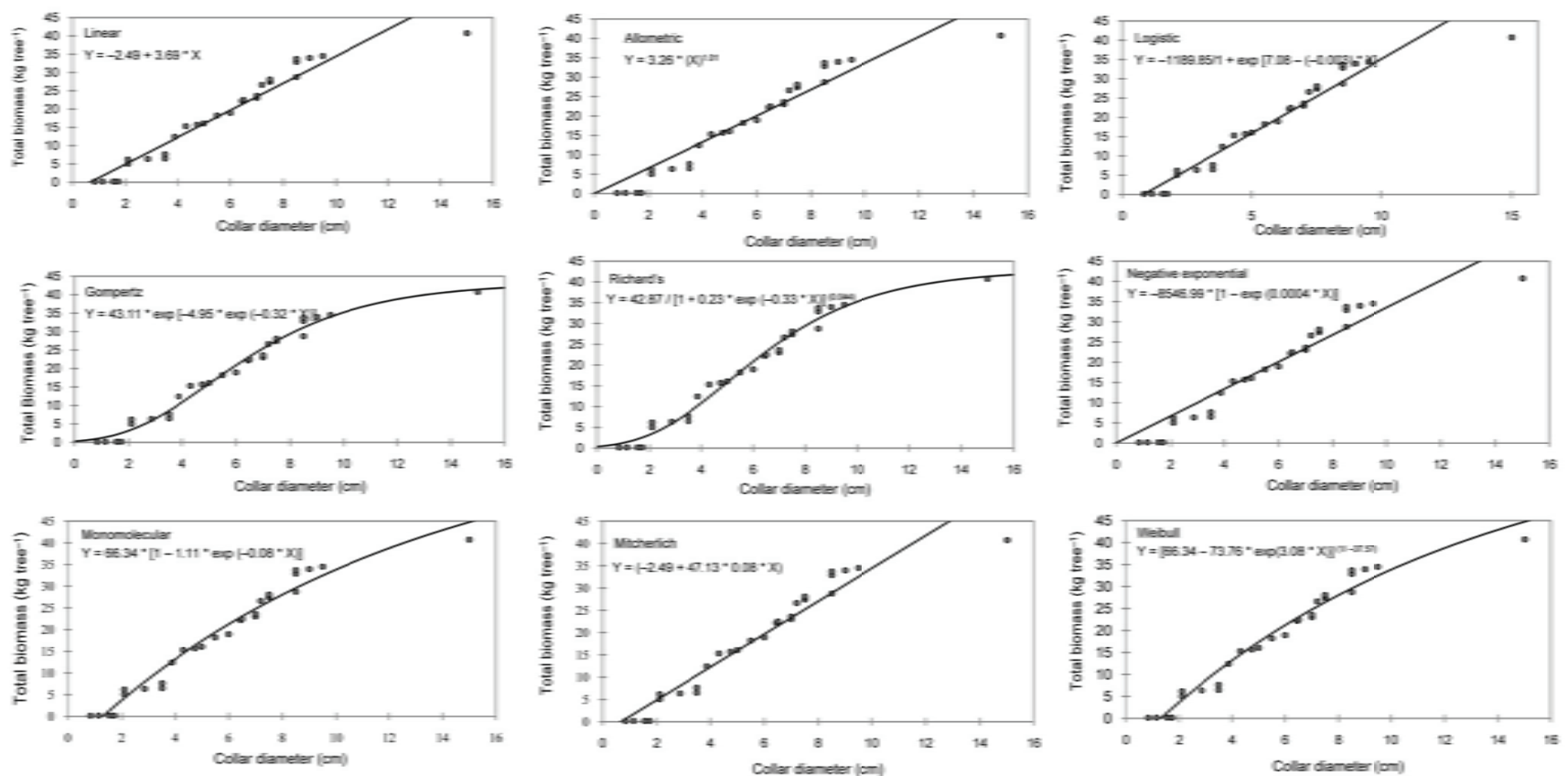

Figure 1. Different growth models fitted to the observed dataset (80\%) of total biomass versus collar diameter in Psidium guajava.
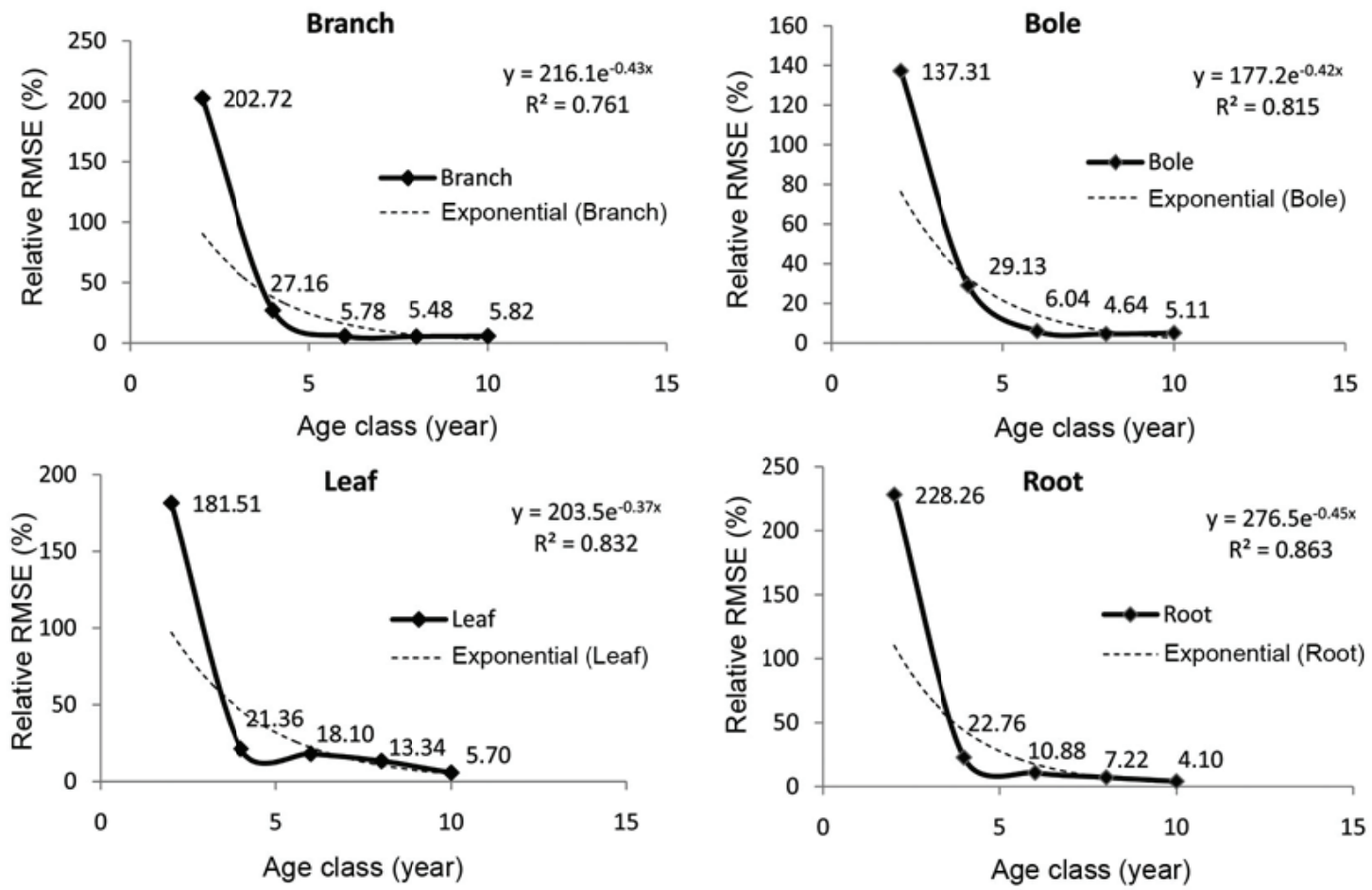

Figure 2. Plot of relative root mean square error (RMSE) of biomass attributes of $P$. guajava with age of plants.

Populus deltoids estimated by $D^{2} H$ (where $D$ represents $\mathrm{DBH}$ and $H$ represents total tree height). Therefore, it is better to use easily measurable variable $\mathrm{CD}$, which does not require measurement of plant height by the growers. Several researchers observed that non-destructive estimation of tree biomass and carbon stocks using diameter is reliable ${ }^{15,16}$. A scatter plot between total biomass and CD was drawn to determine the shape of the function to be fitted on the data (Figure 1). It is clear from this scatter plot that the candidate functions usually adopted for modelling total biomass-CD curves will fit the observed dataset.

CURRENT SCIENCE, VOL. 120, NO. 10, 25 MAY 2021 
RESEARCH ARTICLES

Table 2. Estimates of parameter, adjusted $R^{2}$ values and $\mathrm{AIC}_{\mathrm{c}}$ of various models fitted on $80 \%$ dataset for total biomass prediction in $P$. guajava

\begin{tabular}{|c|c|c|c|c|c|c|c|}
\hline \multirow[b]{2}{*}{ Function/model } & \multirow[b]{2}{*}{ Functional form } & \multicolumn{4}{|c|}{ Parameter estimates } & \multirow[b]{2}{*}{ Adjusted $R^{2}$} & \multirow[b]{2}{*}{$\mathrm{AICc}$} \\
\hline & & $a$ & $b$ & $c$ & $d$ & & \\
\hline Linear & $Y=a+b X+\varepsilon$ & -2.489 & 3.689 & - & - & 0.930 & 97.29 \\
\hline Allometric & $Y=a X^{b}+\varepsilon$ & 3.264 & 1.012 & - & - & 0.928 & 97.34 \\
\hline Logistic & $Y=a / 1+\exp (c-b X)+\varepsilon$ & -1189.852 & -0.003 & 7.079 & - & 0.924 & 94.80 \\
\hline Gompertz & $Y=a \exp (-b \exp (-c X))+\varepsilon$ & 43.114 & 4.952 & 0.320 & - & 0.971 & 93.00 \\
\hline Richard's & $Y=a /(1+b \exp (-c X))^{(1 / d)}+\varepsilon$ & 42.868 & 0.234 & 0.330 & 0.044 & 0.981 & 90.13 \\
\hline Negative exponential & $Y=a(1-\exp (-b X))+\varepsilon$ & -8546.994 & -0.00039 & - & - & 0.930 & 97.30 \\
\hline Monomolecular & $Y=a(1-b \exp (-c X))+\varepsilon$ & 66.335 & 1.112 & 0.082 & - & 0.965 & 93.50 \\
\hline Mitcherlich & $Y=(a-b c X)+\varepsilon$ & -2.489 & -47.129 & 0.078 & - & 0.927 & 94.70 \\
\hline Weibull & $Y=(a-b \exp (-c X))+\varepsilon$ & 66.335 & 73.761 & -3.079 & -37.574 & 0.964 & 90.64 \\
\hline
\end{tabular}

$Y$, Dependent growth variable; $X$, Independent growth variable; $\varepsilon$, Additive error term.

Table 3. Estimation and validation of different models of total biomass-collar diameter on $20 \%$ dataset in $P$. guajava

\begin{tabular}{|c|c|c|c|c|c|c|c|c|c|}
\hline \multirow[b]{2}{*}{ Function/model } & \multirow[b]{2}{*}{ Mean residual } & \multicolumn{2}{|c|}{$\begin{array}{l}\% \text { Confidence } \\
\text { interval of } \\
\text { mean residual }\end{array}$} & \multirow[b]{2}{*}{$\begin{array}{l}\text { Paired } t \text {-test value } \\
\quad(P \text {-value })\end{array}$} & \multicolumn{2}{|c|}{$\begin{array}{c}\text { Parameter estimates } \\
\text { for predicted }= \\
a+b \times \text { observed }\end{array}$} & \multirow[b]{2}{*}{$\begin{array}{c}\mathrm{RMSE}^{*} \\
\left(\mathrm{~kg} \mathrm{tree}^{-1}\right)\end{array}$} & \multirow[b]{2}{*}{$\begin{array}{c}\text { Relative } \\
\text { RMSE (\%) }\end{array}$} & \multirow[b]{2}{*}{$\operatorname{Bias}(\%)$} \\
\hline & & $\begin{array}{l}\text { Lower } \\
\text { bound }\end{array}$ & $\begin{array}{l}\text { Upper } \\
\text { bound }\end{array}$ & & $a$ & $b$ & & & \\
\hline Linear & 0.000 & -1.174 & 1.174 & $1.559 \times 10^{-8}(1.000)$ & -2.383 & 1.071 & 3.200 & 17.95 & 0 \\
\hline Allometric & 0.574 & -0.672 & 1.819 & $0.942(0.354)$ & -0.192 & 0.984 & 3.446 & 19.33 & 57.38 \\
\hline Logistic & 0.039 & -1.174 & 1.252 & $0.066(0.948)$ & -3.285 & 1.118 & 3.367 & 18.89 & 3.93 \\
\hline Gompertz & 0.083 & -0.515 & 0.681 & $0.284(0.779)$ & 0.168 & 0.988 & 1.720 & 9.65 & 17.60 \\
\hline Richard's & 0.076 & -0.520 & 0.672 & $0.261(0.796)$ & 0.032 & 1.001 & 1.692 & 9.49 & 8.29 \\
\hline Negative exponential & 0.606 & -0.640 & 1.851 & $0.995(0.328)$ & 0.059 & 0.973 & 3.452 & 19.36 & 60.57 \\
\hline Monomolecular & $2.559 \times 10^{-5}$ & -0.814 & 0.814 & $6.434 \times 10^{-5}(1.000)$ & 1.534 & 0.931 & 2.258 & 12.67 & 0.002 \\
\hline Mitcherlich & $9.966 \times 10^{-9}$ & -1.174 & 1.174 & $1.736 \times 10^{-8}(1.000)$ & -2.383 & 1.071 & 3.258 & 18.27 & 0 \\
\hline Weibull & $1.277 \times 10^{-4}$ & -0.813 & 0.814 & $3.211 \times 10^{-4}(1.000)$ & 1.534 & 0.931 & 2.301 & 12.91 & 0.013 \\
\hline Standard value & 0 & & & 0 & 0 & 1 & & & \\
\hline
\end{tabular}

*RMSE, Root mean square error.

Table 2 depicts parameter estimates of all the nine models and the associated statistics fitted on the dataset. All the growth models with adjusted $R^{2}$ (observed versus predicted) higher than 0.924 for the given dataset show equal efficiency of all the nine functions. Richard's model recorded the highest adjusted $R^{2}$ value of 0.981 and to judge the best fit of growth function, $R^{2}$ value alone should not be used as single criterion ${ }^{17,18}$. While selecting the best model, validation and behaviour of the growth function fitted with impendent variable inside and outside the observed range should also be considered. AIC is a measure to judge the relative quality of statistical models for any given data and provides a means for model selection ${ }^{19}$. Hurvich and Tsai $^{20}$ further refined this AIC to correct for small data samples as $\mathrm{AIC}_{\mathrm{c}}$ (AIC with a correction for finite sample sizes). $\mathrm{AIC}_{\mathrm{c}}$ is generally used in place of AIC to assign the best model having the lowest $\mathrm{AIC}_{\mathrm{c}}$ (or AIC) score. Richard's model recorded the lowest $\mathrm{AIC}_{\mathrm{c}}$ of 90.13 among the fitted models, followed by Weibull $\left(\mathrm{AIC}_{\mathrm{c}}=90.64\right)$.

The nonlinear growth models, namely monomolecular and Weibull suffers from negative values of predicted variate and are unsuitable for prediction purpose. Further, Richard's model has the lowest RMSE of $1.692 \mathrm{~kg}^{-1}$ tree $^{-1}$ and is best suited for prediction among six nonlinear growth models, viz. allometric, logistic, Gompertz, Richard's, negative exponential and Mitcherlich. Comparing the Gompertz and Richard's models based on $\mathrm{AIC}_{\mathrm{c}}$, the latter model outperformed the former having the lowest $\mathrm{AIC}_{\mathrm{c}}$ and was found suitable for prediction. The relative RMSE of biomass components gradually decreased with increasing age of guava plant (Figure 2).

For estimation and validation of the models, all the datasets of total biomass were randomly divided into $80 \%$ and $20 \%$ mutually exclusive and independent observations respectively. The following two criteria need to be followed by the residual measures (difference between observed and predicted values) for perfect models:

(1) The $a$ and $b$ values of linear regression between observed and predicted values (obs $=a+b \times$ pred) should approach 0 and 1 respectively.

(2) The $t$ and $P$-values of the paired $t$-test of observed and predicted values should approach 0 and 1 respectively.

Table 3 presents the results of these evaluated models. However, the linear model is not recommended for prediction purposes due to the problem of negative estimation of $\operatorname{size}^{21}$, i.e. there is negative value of predicted biomass for lower values of explanatory variate (CD). 

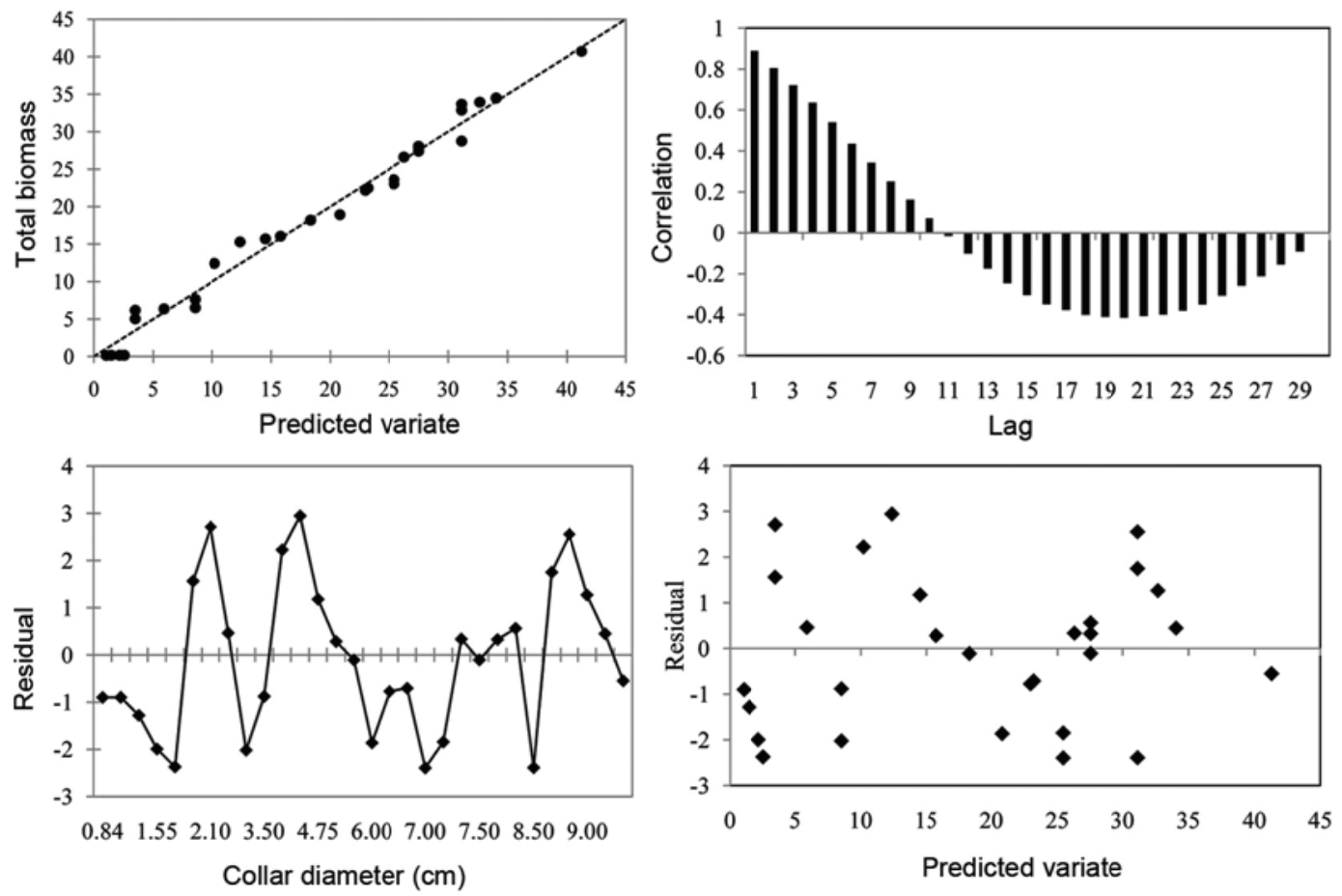

Figure 3. Plot of residual against predicted variate and explanatory variate.

Table 4. Richard's model $\left(Y=a /(1+b \exp (-c X))^{(1 / d)}+\varepsilon\right)$ fitted to different biomass attributes with collar diameter of $P$. guajava

\begin{tabular}{|c|c|c|c|c|c|c|c|c|}
\hline \multirow{2}{*}{$\begin{array}{l}\text { Biomass } \\
\text { component }\end{array}$} & \multirow[b]{2}{*}{ Parameters } & \multirow[b]{2}{*}{ Estimates } & \multirow{2}{*}{$\begin{array}{l}\text { Residual mean } \\
\text { standard error }\end{array}$} & \multicolumn{2}{|c|}{ Wald confidence interval $95 \%$} & \multirow[b]{2}{*}{ Adjusted $R^{2}$} & \multirow[b]{2}{*}{$t$-value } & \multirow[b]{2}{*}{$P$-value } \\
\hline & & & & Lower & Upper & & & \\
\hline \multirow[t]{4}{*}{ Branch } & $a$ & 12.695 & 0.514 & -0.167 & 0.197 & 0.980 & 0.170 & 0.866 \\
\hline & $b$ & 0.032 & & & & & & \\
\hline & $c$ & 0.326 & & & & & & \\
\hline & $d$ & 0.006 & & & & & & \\
\hline \multirow[t]{4}{*}{ Bole } & $a$ & 9.891 & 0.463 & -0.146 & 0.180 & 0.976 & 0.213 & 0.833 \\
\hline & $b$ & 0.627 & & & & & & \\
\hline & $c$ & 0.386 & & & & & & \\
\hline & $d$ & 0.103 & & & & & & \\
\hline \multirow[t]{4}{*}{ Leaf } & $a$ & 11.125 & 0.567 & -0.148 & 0.251 & 0.976 & 0.526 & 0.603 \\
\hline & $b$ & 0.722 & & & & & & \\
\hline & $c$ & 0.318 & & & & & & \\
\hline & $d$ & 0.123 & & & & & & \\
\hline \multirow[t]{4}{*}{ Root } & $a$ & 10.862 & 0.378 & -0.115 & 0.152 & 0.981 & 0.278 & 0.783 \\
\hline & $b$ & 1.690 & & & & & & \\
\hline & $c$ & 0.319 & & & & & & \\
\hline & $d$ & 0.228 & & & & & & \\
\hline \multirow[t]{4}{*}{ AGB } & $a$ & 28.099 & 1.643 & -0.538 & 0.623 & 0.977 & 0.150 & 0.882 \\
\hline & $b$ & 8.483 & & & & & & \\
\hline & $c$ & 0.505 & & & & & & \\
\hline & $d$ & 0.652 & & & & & & \\
\hline \multirow[t]{4}{*}{ BGB } & $a$ & 10.862 & 0.378 & -0.115 & 0.152 & 0.981 & 0.278 & 0.783 \\
\hline & $b$ & 1.690 & & & & & & \\
\hline & $c$ & 0.319 & & & & & & \\
\hline & $d$ & 0.228 & & & & & & \\
\hline \multirow[t]{4}{*}{ Total biomass } & $a$ & 42.868 & 1.693 & -0.515 & 0.681 & 0.981 & 0.284 & 0.779 \\
\hline & $b$ & 0.234 & & & & & & \\
\hline & $c$ & 0.330 & & & & & & \\
\hline & $d$ & 0.044 & & & & & & \\
\hline
\end{tabular}

$Y$, Component biomass $\left(\mathrm{kg}\right.$ tree $\left.{ }^{-1}\right)$ and $X$, collar diameter $(\mathrm{cm})$. 
RESEARCH ARTICLES

Table 5. Component-wise predicted biomass estimates $\left(\mathrm{Mg} \mathrm{ha}^{-1}\right)$ and mean annual increment $\left(\mathrm{Mg} \mathrm{ha}^{-1}\right.$ year $\left.^{-1}\right)$ in $P$. guajava

\begin{tabular}{|c|c|c|c|c|c|c|c|c|c|}
\hline \multirow[b]{2}{*}{ Age (years) } & \multirow{2}{*}{$\begin{array}{l}\text { Average collar } \\
\text { diameter }(\mathrm{cm})\end{array}$} & \multicolumn{6}{|c|}{ Predicted biomass of different tree components } & \multirow{2}{*}{$\begin{array}{l}\text { Total biomass } \\
(\mathrm{AGB}+\mathrm{BGB})\end{array}$} & \multirow{2}{*}{$\begin{array}{c}\text { MAI } \\
\left(\mathrm{mg} \mathrm{ha}^{-1} \text { year }^{-1}\right)\end{array}$} \\
\hline & & Branch & Bole & Leaf & Root & AGB & BGB & & \\
\hline 2 & $1.37 \pm 0.21$ & $\begin{array}{c}0.13 \pm 0.03 \\
(24.0)\end{array}$ & $\begin{array}{c}0.14 \pm 0.03 \\
(25.9)\end{array}$ & $\begin{array}{c}0.14 \pm 0.02 \\
(25.9)\end{array}$ & $\begin{array}{c}0.12 \pm 0.02 \\
\quad(22.2)\end{array}$ & $\begin{array}{c}0.42 \pm 0.09 \\
(77.7)\end{array}$ & $\begin{array}{c}0.12 \pm 0.02 \\
\quad(22.2)\end{array}$ & $0.54 \pm 0.11$ & $0.27 \pm 0.05$ \\
\hline 4 & $3.36 \pm 0.32$ & $\begin{array}{c}0.61 \pm 0.10 \\
(27.3)\end{array}$ & $\begin{array}{c}0.60 \pm 0.10 \\
(26.8)\end{array}$ & $\begin{array}{c}0.52 \pm 0.08 \\
(23.3)\end{array}$ & $\begin{array}{c}0.42 \pm 0.06 \\
(18.7)\end{array}$ & $\begin{array}{c}1.80 \pm 0.29 \\
(80.3)\end{array}$ & $\begin{array}{c}0.42 \pm 0.06 \\
(18.7)\end{array}$ & $2.24 \pm 0.35$ & $0.56 \pm 0.08$ \\
\hline 6 & $5.70 \pm 0.30$ & $\begin{array}{c}1.52 \pm 0.12 \\
(28.7)\end{array}$ & $\begin{array}{c}1.40 \pm 0.10 \\
(26.4)\end{array}$ & $\begin{array}{c}1.24 \pm 0.10 \\
(23.4)\end{array}$ & $\begin{array}{c}1.04 \pm 0.09 \\
(19.6)\end{array}$ & $\begin{array}{c}4.25 \pm 0.32 \\
(80.2)\end{array}$ & $\begin{array}{c}1.04 \pm 0.09 \\
(19.6)\end{array}$ & $5.30 \pm 0.41$ & $0.88 \pm 0.07$ \\
\hline 8 & $7.28 \pm 0.10$ & $\begin{array}{c}2.13 \pm 0.03 \\
(29.1)\end{array}$ & $\begin{array}{c}1.89 \pm 0.03 \\
(25.8)\end{array}$ & $\begin{array}{c}1.75 \pm 0.03 \\
(23.9)\end{array}$ & $\begin{array}{c}1.53 \pm 0.03 \\
(20.9)\end{array}$ & $\begin{array}{c}5.80 \pm 0.09 \\
(79.2)\end{array}$ & $\begin{array}{c}1.53 \pm 0.03 \\
(20.8)\end{array}$ & $7.32 \pm 0.12$ & $0.92 \pm 0.02$ \\
\hline 10 & $9.83 \pm 1.05$ & $\begin{array}{c}2.71 \pm 0.14 \\
(29.2)\end{array}$ & $\begin{array}{c}2.29 \pm 0.08 \\
(24.7)\end{array}$ & $\begin{array}{c}2.28 \pm 0.13 \\
\quad(22.86)\end{array}$ & $\begin{array}{c}2.08 \pm 0.15 \\
(22.4)\end{array}$ & $\begin{array}{c}7.18 \pm 0.31 \\
(77.5)\end{array}$ & $\begin{array}{c}2.08 \pm 0.15 \\
(22.4)\end{array}$ & $9.26 \pm 0.44$ & $0.93 \pm 0.04$ \\
\hline
\end{tabular}

Values in parenthesis indicate $\%$ allocation in different tree components and \pm values indicate standard error; MAI, Mean annual increment.

Based on validation criteria (approaching closely the standard values), Richard's model $(Y=a$ / $\left.(1+b \exp (-c X))^{(1 / d)}+\varepsilon\right)$ was found to be the best suitable for prediction purposes. Plots of residual diagnostics between total biomass and CD fitted in Richard's function also ensure the requisites of regression analysis. The residual is estimated as the difference between the observed and predicted values and is known as the error of prediction. Theoretically, the residual should be independently and normally distributed with mean zero and constant variance. The Anderson-Darling test was used for normality test of residuals with the assumption that residuals are normally distributed according to the null hypothesis. Further, the residuals are not being continuously over/ under estimated for total biomass, as was evidenced from the plots of residuals against the explanatory variate (CD) and predicted variate (Figure 3). Hence, Richard's model was selected for predicting biomass in different components due to higher adjusted $R^{2}$, lower RMSE and lower $\mathrm{AIC}_{\mathrm{c}}$ values in the model-fitting stage.

The different parameters of Richard's model were calculated by fitting the different biomass components, i.e. bole (stem wood), branches, leaves and roots of 30 guava trees aged 2-10 years in the model using collar diameter of the tree as the independent variable (Table 4). The adjusted $R^{2}$ for the fitted model ranged from 0.976 and 0.981. The highest adjusted $R^{2}$ was found for roots $(0.981)$ followed by branches $(0.980)$, whereas bole and leaves $(0.976)$ recorded the minimum value. The $t$ values were non-significant $(P>0.05)$ for all the biomass components, thus indicating that Richard's model for tree components is well validated. Table 5 presents component-wise predicted biomass estimates of guava orchards of different ages. The total dry biomass in 2-10-year-old guava orchards accounted for $77.5 \%-80.3 \%$ of aboveground components (bole, branch wood and leaves) and ranged from 0.54 to $9.26 \mathrm{Mg} \mathrm{ha}^{-1}$. For young orchards (2-year-old), biomass distribution among tree components followed the order leaves $=$ bole $>$ branches $>$ roots, while highest contribution of branches followed by bole and leaves was recorded in 4-10-year-old Orchards. In contrast, Verma et al. ${ }^{22}$ observed higher allocation of biomass in bole to a maximum of $54.2 \%-55.9 \%$ in the multipurpose Grewia optiva trees. However, branches contributed more biomass than bole in fruit trees. This could be attributed to the fact that $P$. guajava is pruned and trained in such a way that crown surface area increases, which leads to more fruiting and hence more branch biomass and restricted stem dimensions. The branches in P. guajava contributed $24.0 \%-29.2 \%$ of total biomass. Various factors like plant architecture and morphology, age, climatic and edaphic factors, and management practices affect biomass distribution among components of woody plants ${ }^{23,24}$. The predicted biomass of bole ranged from 0.14 to $2.29 \mathrm{Mg} \mathrm{ha}^{-1}$ in 2-10-yearold orchards, while leaf biomass production varied from 0.14 to $2.28 \mathrm{Mg} \mathrm{ha}^{-1}$. This was comparable with the values $\left(0.34-2.61 \mathrm{Mg} \mathrm{ha}^{-1}\right)$ reported by Rathore et al. ${ }^{11}$. The mean annual increment (MAI) ranged from 0.27 to $0.93 \mathrm{Mg} \mathrm{ha}^{-1}$ year $^{-1}$ in 2-10-year-old orchards. The predicted tree biomass variation in guava may be attributed to various factors like growth conditions, site quality, age, stand density, soil nutrient and management practic$\mathrm{es}^{25,26}$. The BGB recorded lower values and was attributed to the low fertility status of the experimental sites leading to less utilization of resources by the weak root systems ${ }^{9}$.

The carbon content in different tree components, viz. bole (stem wood), branches, leaves, total AGB, total BGB and total root biomass was estimated using CHNS analyzer and fitted in the Richard's model to calculate the predicted carbon content (Table 6). In Richard's model, the independent collar diameter value of the tree is required to arrive at the carbon content of tree components with the corresponding parameter estimates. The $t$ values were non-significant $(P>0.05)$ for estimating carbon content in all the biomass components, thus indicating that Richard's model is well validated. The average carbon content of different tree components of guava ranged between $43.3 \%$ and $46.1 \%$. Several researchers 
Table 6. Richard's model $\left(Y=a /(1+b \exp (-c X))^{(1 / d)}+\varepsilon\right)$ fitted to biomass carbon attributes with CD of $P$. guajava

\begin{tabular}{|c|c|c|c|c|c|c|c|c|}
\hline \multirow{2}{*}{$\begin{array}{l}\text { Biomass } \\
\text { component }\end{array}$} & \multirow[b]{2}{*}{ Parameters } & \multirow[b]{2}{*}{ Estimates } & \multirow{2}{*}{$\begin{array}{c}\text { Residual } \\
\text { standard error }\end{array}$} & \multicolumn{2}{|c|}{ Wald confidence interval 95\% } & \multirow[b]{2}{*}{ Adjusted $R^{2}$} & \multirow[b]{2}{*}{$t$-value } & \multirow[b]{2}{*}{$P$-value } \\
\hline & & & & Lower & Upper & & & \\
\hline Branch & $\begin{array}{l}a \\
b \\
c \\
d\end{array}$ & $\begin{array}{l}5.592 \\
0.298 \\
0.324 \\
0.055\end{array}$ & $4.574 \times 10^{-14}$ & -0.009 & 0.012 & 0.999 & 0.293 & 0.771 \\
\hline Bole & $\begin{array}{l}a \\
b \\
c \\
d\end{array}$ & $\begin{array}{l}4.202 \\
3.557 \\
0.456 \\
0.375\end{array}$ & 0.089 & -0.006 & 0.063 & 0.996 & 1.680 & 0.367 \\
\hline Leaf & $\begin{array}{l}a \\
b \\
c \\
d\end{array}$ & $\begin{array}{l}5.171 \\
0.308 \\
0.305 \\
0.058\end{array}$ & $2.808 \times 10^{-15}$ & -0.001 & 0.001 & 0.999 & 0.061 & 0.952 \\
\hline Root & $\begin{array}{l}a \\
b \\
c \\
d\end{array}$ & $\begin{array}{l}4.811 \\
5.817 \\
0.378 \\
0.491\end{array}$ & 0.001 & -0.008 & 0.009 & 0.999 & 0.073 & 0.943 \\
\hline AGB & $\begin{array}{l}a \\
b \\
c \\
d\end{array}$ & $\begin{array}{r}14.755 \\
1.122 \\
0.362 \\
0.169\end{array}$ & 0.002 & -0.001 & 0.001 & 0.999 & 0.593 & 0.557 \\
\hline BGB & $\begin{array}{l}a \\
b \\
c \\
d\end{array}$ & $\begin{array}{l}4.811 \\
5.817 \\
0.378 \\
0.491\end{array}$ & 0.001 & -0.008 & 0.009 & 0.999 & 0.073 & 0.943 \\
\hline Total biomass & $\begin{array}{l}a \\
b \\
c \\
d\end{array}$ & $\begin{array}{r}19.738 \\
1.395 \\
0.349 \\
0.204\end{array}$ & 0.046 & -0.015 & 0.017 & 0.999 & 0.085 & 0.933 \\
\hline
\end{tabular}

Table 7. Estimation of attribute-wise carbon stock and stored $\mathrm{CO}_{2}\left(\mathrm{Mg} \mathrm{ha}^{-1}\right)$ in $P$. guajava

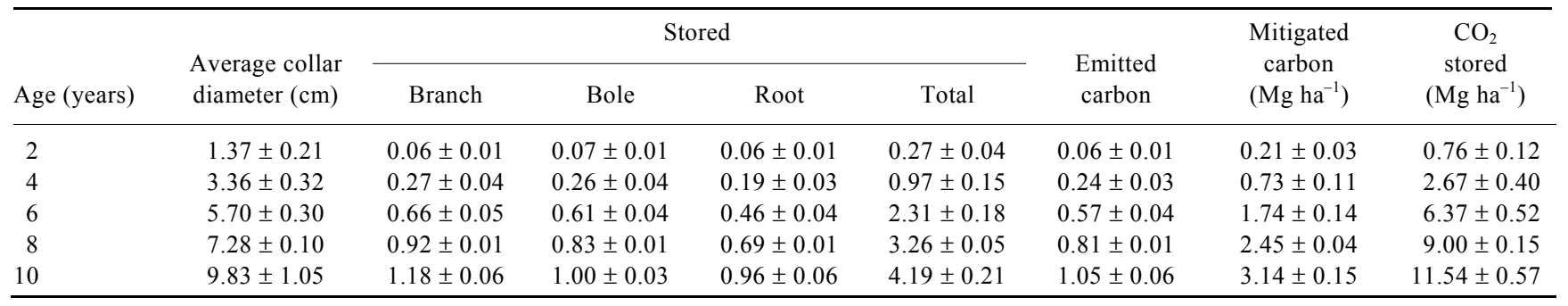

have shown that the $\mathrm{C}$ concentration of tree components or tree species is below 50\% (refs 27 and 28). In the present study, leaves recorded maximum carbon content $(46.1 \%)$, followed by roots $(45.6 \%)$, bole $(43.9 \%)$ and branches $(43.3 \%)$. The biomass carbon stock stored in guava orchards (branches, bole and roots) varied from 0.27 to $4.19 \mathrm{Mg} \mathrm{ha}^{-1}$ in 2-10-year-old orchards (Table 7). The observed values of biomass carbon stock in guava are comparable to those reported (1.23-20.82 $\mathrm{Mg} \mathrm{C} \mathrm{ha}^{-1}$ ) in different agroforestry systems of Populus deltoids, Terminalia arjuna, Acacia catechu and Pinus roxburg$h i i^{29,30}$. Previous studies found that biomass C storage in temperate forests exceeded that of tropical forests, leading to the conclusion that cool temperature in combination with moderate precipitation favours biomass carbon accumulation $^{31,32}$. The emitted carbon corresponding to carbon stored in leaves varied from 0.06 to $1.05 \mathrm{Mg} \mathrm{ha}^{-1}$ in 2-10-year-old guava orchards. The carbon mitigation in these orchards varied from 0.21 to $3.14 \mathrm{Mg} \mathrm{ha}^{-1}$, which sequestered $0.76-11.54 \mathrm{Mg} \mathrm{ha}^{-1} \mathrm{CO}_{2}$ from the atmosphere. The mitigation of $\mathrm{CO}_{2}$ by plants is directly related to biomass production in different components. The current carbon mitigation potential and the number of carbon credits $\left(1 \mathrm{C}\right.$ credit $\left.=1 \mathrm{Mg} \mathrm{CO}_{2}\right)$ produced by orchards of different age classes are likely to increase with increase in collar diameter.

\section{Conclusion}

The dry biomass and carbon stock in different tree components could be estimated from Richard's equation using collar diameter as an independent variable. The 
validity of the developed models is within the collar diameter range of guava orchards considered during sampling, because they do not include other sources of variation. The guava orchards in rainfed condition under hot and sub-humid climate make significant contributions towards atmospheric $\mathrm{CO}_{2}$ sequestration, simultaneously reducing emissions from deforestation. These findings will help in better understanding of $\mathrm{C}$ stocks and dynamics in $P$. guajava orchards and can be used in orchard management activities to enhance $\mathrm{C}$ sequestration while earning significant $\mathrm{C}$ credits. Hence its importance of guava trees in reducing GHGs in the atmosphere vis-à-vis global warming deserves more attention and further studies at the country level.

1. Houghton, R. A., Why are estimates of the terrestrial carbon balance so different? Global Change Biol., 2003, 9, 500-509.

2. IPCC, Climate Change 2007: Synthesis Report: Contribution of Working Groups I, II and III to the Fourth Assessment Report. Intergovernmental Panel on Climate Change, Geneva, Switzerland, 2007.

3. https:/www.esrl.noaa.gov/gmd/ccgg/trends/ (assessed on 25 June 2017).

4. Jackson, M., Ford-Lloyd, B. and Parry, M., Plant Genetic Resources and Climate Change, CAB International, Manila, Philippines, 2014.

5. NHB, Final area and production estimates for horticulture crops for 2014-2015, National Horticulture Board, New Delhi, 2015; http://nhb.gov.in/PDFViwer.aspx?enc=3ZOO8K5CzcdC/Yq6HcdIxC0U1kZZenFuNVXacDLxz28=

6. UNFCCC, Kyoto Protocol Reference Manual, United Nations Framework Convention on Climate Change, Bonn, Germany, 2008, p. 33.

7. Foresta, de H., Sommariba, E., Temu, A., Boulanger, F. H. and Desiree, G. M., Towards the assessment of trees outside forests: resources assessment, Working Paper No. 183. Food and Agriculture Organization, Rome, Italy, 2013, p. 335.

8. Fassnacht, F. E., Hartig, F., Latifi, H., Berger, C., Hernández, J. and Corvalán, P., Importance of sample size, data type and prediction method for remote sensing-based estimations of aboveground forest biomass. Remote Sensing Environ., 2014, 154, 102-114.

9. Naik, S. K., Maurya, S., Mukherjee, D., Singh, A. K. and Bhatt, B. $\mathrm{P}$., Rates of decomposition and nutrient mineralization of leaf litter from different orchards under hot and dry sub-humid climate. Arch. Agron. Soil Sci., 2018, 64, 560-573.

10. Naik, S. K., Shinde, R., Mali, S. S., Jha, B. K., Das, B. and Singh, A. K., Diagnosis of nutrient deficiency and its management in horticultural crops. Technical Bulletin No. R-59/Ranchi-26, Research Centre, Ranchi, ICAR Research Complex for Eastern Region, Patna, India, 2016.

11. Rathore, A. C. et al., Predictive models for biomass and carbon stock estimation in Psidium guajava on bouldery riverbed lands in North-Western Himalayas, India. Agrofor. Syst., 2018, 92, 171-182.

12. Naik, S. K., Sarkar, P. K., Das, B., Singh, A. K. and Bhatt, B. P., Predictive models for dry biomass and carbon stock estimation in Litchi chinensis under hot and dry sub-humid climate. Arch. Agron. Soil Sci., 2018, 64, 1366-1378.

13. Wilkinson, L. and Coward, M., SYSTAT: statistics-II, Version 12. Systat Software Inc, San Jose, CA, USA, 2007.

14. Rizvi, R. H., Khare, D. and Dhillon, R. S., Statistical models for aboveground biomass of Populus deltoids planted in agroforestry in Haryana. Trop. Ecol., 2008, 49, 35-42.

15. Rizvi, R. H., Dhyani, S. K., Yadav, R. S. and Ramesh, S., Biomass production and carbon stock of poplar agroforestry systems in
Yamunanagar and Saharanpur districts of northwestern India. Curr. Sci., 2011, 100, 736-742.

16. Arora, G., Chaturvedi, S., Kaushal, R., Nain, A., Tewari, S., Alam, N. M. and Chaturvedi, O. P., Growth, biomass, carbon stocks and sequestration in age series Populus deltoides plantations in Tarai region of Central Himalaya. Turk. J. Agric. For., 2013, 38, 550 560.

17. Prajneshu and Chandran, K. P., Comparison of compound growth rates in agriculture: revisited. Agric. Econ. Res. Rev., 2005, 18, 317-324.

18. Ajit, Rai, P., Handa, A. K., Choudhary, I. S. and Uma, C., Allometry for estimating above ground biomass of Eucalyptus tereticornis under energy and boundary plantations in central India. Ann. Arid Zone, 2006, 45, 175-182.

19. Akaike, H., Information theory as an extension of the maximum likelihood principle. In Second International Symposium on Information Theory (eds Petrov, B. N. and Csaki, F.), Akademiai Kiado, Budapest, 1973, pp. 267-281.

20. Hurvich, C. and Tsai, C. L., Regression and time series model selection in small samples. Biometrica, 1989, 76, 297-293.

21. Ajit, Srivastava, P. N., Gupta, V. K. and Solanki, K. R., Linear tree growth models: a limitation of negative estimation of size. Indian For., 2000, 126, 1336-1341.

22. Verma, A. et al., Predictive models for biomass and carbon stocks estimation in Grewia optiva on degraded lands in Western Himalaya. Agrofor. Syst., 2014, 88, 895-905.

23. Gourlet-Fleury, S. and Houllier, F., Modelling diameter increment in a lowland evergreen rain forest in French Guiana. For. Ecol. Manage, 2000, 131, 269-289.

24. Veronica, G., Luisa, P. P. and Gerardo, R., Allometric relations for biomass partitioning of Nothofagus Antarctica trees of different crown classes over a site quality gradient. For. Ecol. Manage., 2010, 259, 1118-1126.

25. Noh, N. J., Son, Y., Lee, S. K., Seo, K. W. and Heo, S. J., Carbon and nitrogen storage in an age-sequence of Pinus densiflora stands in Korea. Sci. China Life Sci., 2010, 53, 822-830.

26. Cao, J., Wang, X., Tian, Y., Wen, Z. and Zha, T., Pattern of carbon allocation across three different stages of stand development of a Chinese pine (Pinus tabulaeformis) forest. Ecol. Res., 2012, 27, 883-892.

27. Li, X., Yi, M. J., Son, Y., Park, P. S. and Lee, K. H., Biomass and carbon storage in an age-sequence of Korean pine (Pinus koraiensis) plantation forests in Central Korea. J. Plant Biol., 2011, 54, 33-42.

28. Naik, S. K., Maurya, S. and Bhatt, B. P., Soil organic carbon stocks and fractions in different orchards of eastern plateau and hill region of India. Agrofor. Syst., 2017, 91, 541-552.

29. Koul, D. N. and Panwar, P., Prioritizing land-management options for carbon sequestration potential. Curr. Sci., 2008, 95, 658-663.

30. Goswami, S., Verma, K. S. and Kaushal, R., Biomass and carbon sequestration in different agroforestry systems of a Western Himalayan watershed. Biol. Agric. Hortic., 2014, 30, 88-96.

31. Smithwick, E. A. H., Harmon, M. E., Remillard, S. M., Acker, S. and Franklin, J., Potential upper bounds of carbon stores in forests of the Pacific North-West. Ecol. Appl., 2002, 12, 1303-1317.

32. Keith, H., Mackey, B. G. and Lindenmayer, D. B., Re-evaluation of forest biomass carbon stocks and lessons from the world's most carbon-dense forests. Proc. Natl. Acad. Sci. USA, 2009, 106, $11635-11640$.

ACKNOWLEDGEMENTS. We thank the Indian Council of Agricultural Research, New Delhi, for providing funds and the necessary facilities to carry out this study. We also thank the anonymous reviewers for useful suggestions.

Received 17 December 2019; revised accepted 11 January 2021

doi: $10.18520 / \mathrm{cs} / \mathrm{v} 120 / \mathrm{i} 10 / 1627-1635$ 